positron emission tomography and magnetic resonance imaging. Am J Psychiatry 2000;157:1994-2001.

29. Garber HJ, Ritvo ER. Magnetic resonance imaging of the posterior fossa in autistic adults. Am J Psychiatry 1992;149:245247.

30. Courchesne E, Muller R, Saitoh O. Brain weight in autism: normal in the majority of cases, megalencephalic in rare cases. Neurology 1999;52:1057-1059.

31. Bauman ML. Brief report: neuroanatomic observations of the brain in pervasive developmental disorders. J Autism Dev Disord 1996;26:199-203.

32. Minshew NJ. Autism. In: Berg BO, ed. Principles of child neurology. New York: McGraw Hill, Inc, 1996:1713-1730.

33. LeCouteur A, Rutter M, Lord C, et al. Autism diagnostic interview: a standardized investigator-based instrument. J Autism Dev Disord 1989;19:363-387.

34. Lord C, Rutter M, LeCouteur A. Autism Diagnostic Interview-Revised: a revised version of a diagnostic interview for caregivers of individuals with possible pervasive developmental disorders. J Autism Dev Disord 1994;24:659-685.

35. Lord C, Rutter M, Goode S, et al. Autism diagnostic observation schedule: a standardized observation of communicative and social behavior. J Autism Dev Disord 1989;19:185-212.

36. Lord C, Risi S, Lambrecht L, et al. The Autism Diagnostic Observation Schedule-Generic: a standard measure of social and communication deficits associated with the spectrum of autism. J Autism Dev Disord 2000;30:205-223.

37. Buchanan RW, Vladar K, Barta PE, Pearlson GD. Structural evaluation of the prefrontal cortex in schizophrenia. Am J Psychiatry 1998;155:1049-1055.

38. Aylward EH, Anderson NB, Bylsma F, et al. Frontal lobe volume in patients with Huntington's disease. Neurology 1998;50:252-258.

39. Farkas LG. Examination. In: Farkas LG, ed. Antropometry of the head and face. 2nd ed. New York: Raven Press, 1994:3-56.

40. Reiss AL, Abrams MT, Singer HS, Ross JL, Denckla MB Brain development, gender and IQ in children. A volumetric imaging study. Brain 1996;119:1763-1774.

41. Pennington BF, Filipek PA, Lefly D, et al. A twin MRI study of size variations in human brain. J Cogn Neurosci 2000;12: $223-232$.

42. Nelson KB, Grether JK, Croen LA, et al. Neuropeptides and neurotrophins in neonatal blood of children with autism or mental retardation. Ann Neurol 2001;49:597-606.

43. Casey BJ, Giedd JN, Thomas, KM. Structural and functional brain development and its relation to cognitive development. Biol Psychol 2000;54:241-257.

44. Minshew NJ, Luna B, Sweeney JA. Oculomotor evidence for neocortical systems but not cerebellar dysfunction in autism. Neurology 1999;52:917-922.
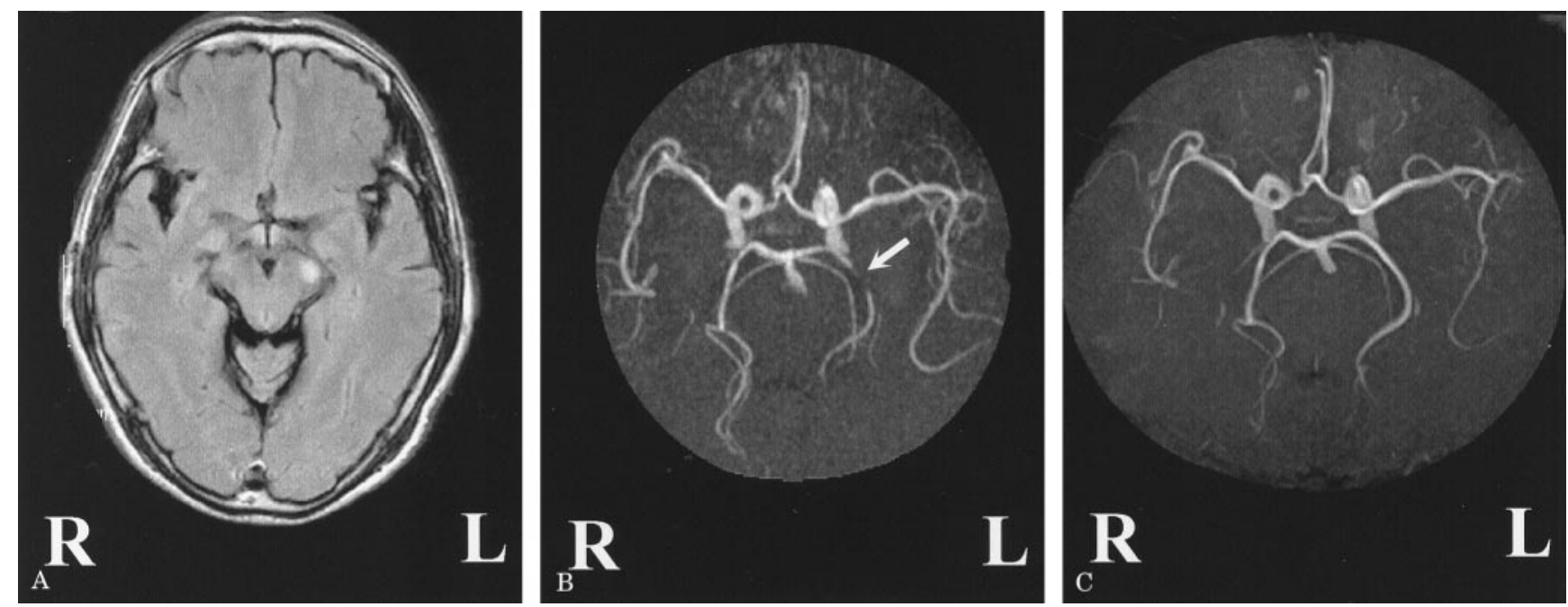

Figure. (A) Axial fluid-attenuated inversion recovery imaging. (B) Collapse imaging of brain MR angiography (MRA) showing stenosis of the left P2 segment (arrow). (C) Collapse imaging of previous brain MRA.

\section{Cerebral peduncular infarction}

K. Ikeda, MD, PhD, A. Kuwajima, MD, Y. Iwasaki, MD, M. Kinoshita, MD, K. Hosozawa, PhD, M. Tamura, MD, N. Samejima, MD, Y. Seki, MD, Tokyo, Japan

A 65-year-old man with hypertension developed mild degree of dysarthria and weakness in the right hand. Neurologic examination showed central paresis of the right face, tongue, and upper limb without ataxia. Fluid-attenuated inversion recovery imaging (1.5 Tesla, Hitachi Medical Stratis II) showed marked hyperintensity signal in the left cerebral peduncle (figure, A). MR angiography (MRA), using a three-dimensional time of flight sequence, disclosed irregularities of the basilar artery and stenosis of the left ambient (P2) segment (see the figure, B), in comparison with previous MRA at age 61 years (see the figure, C).
Lacunar infarction of the cerebral peduncle occurs infrequently and may cause dysarthria-one-hand weakness. ${ }^{1}$ The circulation of cerebral peduncle is supplied by the perforating branches from the posterior communicating arteries and the peduncular perforating arteries and circumflex branches from the posterior cerebral arteries. Those perforating and circumferential branches originate from the precommunical (P1) or P2 segment of the posterior cerebral arteries. ${ }^{2}$ Our images indicate that the stenosis of ipsilateral P2 segment could contribute to cerebral peduncular infarction in our patient.

1. Urban PP, Wicht S, Vukurevic G, et al. Dysarthria in acute ischemic stroke: lesion topography, clinico-radiologic correlation, and etiology. Neurology 2001;56:1021-1027.

2. Zeal AA, Rhoton AL Jr. Microsurgical anatomy of the posterior cerebral artery. J Neurosurg 1978;48:534-559. 


\section{Neurology}

\section{Cerebral peduncular infarction}

K. Ikeda, A. Kuwajima, Y. Iwasaki, et al.

Neurology 2002;59;183

DOI 10.1212/WNL.59.2.183

This information is current as of July 23, 2002

\section{Updated Information \& Services}

References

Subspecialty Collections

Permissions \& Licensing

Reprints including high resolution figures, can be found at: http://n.neurology.org/content/59/2/183.full

This article cites 2 articles, 1 of which you can access for free at: http://n.neurology.org/content/59/2/183.full\#ref-list-1

This article, along with others on similar topics, appears in the following collection(s):

All Imaging

http://n.neurology.org/cgi/collection/all_imaging

Infarction

http://n.neurology.org/cgi/collection/infarction

MRI

http://n.neurology.org/cgi/collection/mri

Information about reproducing this article in parts (figures,tables) or in its entirety can be found online at:

http://www.neurology.org/about/about_the_journal\#permissions

Information about ordering reprints can be found online:

http://n.neurology.org/subscribers/advertise

Neurology ${ }^{\circledR}$ is the official journal of the American Academy of Neurology. Published continuously since 1951, it is now a weekly with 48 issues per year. Copyright . All rights reserved. Print ISSN: 0028-3878. Online ISSN: $1526-632 X$.

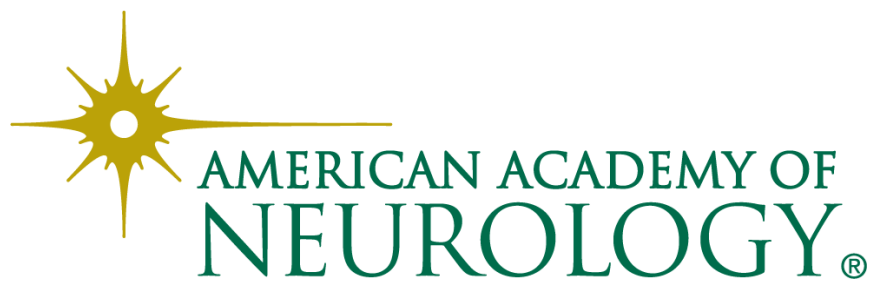

